\title{
Changing incidence of neonatal hypermethioninaemia: implications for the detection of homocystinuria
}

\author{
P. D. WHITEMAN, BARBARA E. CLAYTON, R. S. ERSSER, PAMELA LILLY, AND \\ J. W. T. SEAKINS
}

Department of Chemical Pathology, The Hospital for Sick Children and Institute of Child Health, London

SUMMARY The Guthrie test was used to measure blood methionine concentrations in 670764 neonates during the period from May 1970 to December 1977 . Raised values $(>4 \mathrm{mg} / 100 \mathrm{ml}$; $268 \mu \mathrm{mol} / \mathrm{l})$ were found in 147 babies (6-14 days old) and 55 of these still had raised values when retested 2-6 weeks later. 48 infants had transient hypermethioninaemia of at least 3 weeks' duration, one had a more persistent form associated with abnormal liver function tests, 3 had different forms of homocystinuria, and one infant, who was asymptomatic at the time of detection, had hypermethioninaemia associated with a rapidly fatal form of tyrosinaemia (tyrosinosis). Two infants could not be followed up. Transient hypermethioninaemia has not been detected in this laboratory since 1975. There was a greatly reduced incidence of transient hypermethioninaemia in girls after 1972 and in boys after 1975; this may have been due to recent changes in infant feeding practices in the UK. Homocystinuria was last detected in this laboratory in 1972; the apparent change in incidence is significant $(\mathrm{P}<0.05)$ and suggests that the diagnostic value of this screening procedure should be reassessed.

Neonatal screening for homocystinuria on a national scale is not yet acceptable because of the apparent low incidence of the disease, the uncertainty about the reliability of methods of screening, and about the long-term efficacy of current methods of treatment. Results from different screening centres suggest that the incidence of homocystinuria varies considerably from one area to another, but the extent to which this reflects a true difference in the incidence of the disease or a difference in methodology has been questioned (Thalhammer, 1975; Wilcken and Turner, 1978). Classical homocystinuria can be accompanied by hypermethioninaemia in the neonatal period (Komrower et al., 1966) and this finding forms the basis of one simple screening procedure (Guthrie, 1968). However, hypermethioninaemia does not occur in variant forms of homocystinuria associated

\footnotetext{
Wellcome Research Laboratories, Beckenham, Kent P. D. WHITEMAN, clinical research physician

Academic Block, Southampton General Hospital, Hampshire BARBARA E. CLAYTON, professor of chemical pathology and human metabolism

The Hospital for Sick Children, London

R. S. ERSSER, chief medical laboratory scientific officer PAMELA LILLY, senior medical laboratory scientific officer Institute of Child Health, London

J. W. T. SEAKINS, senior lecturer in clinical biochemistry
}

with defects in the biosynthesis of folate coenzymes (Mudd et al., 1970, 1972) and may sometimes be absent in classical homocystinuria in the first days of life (Komrower et al., 1966; Levy et al., 1971).

Transient hypermethioninaemia in the neonatal period has been associated with a high protein intake and, in premature infants at least, a low hepatic cystathioninase activity may be a contributory factor (Levy et al., 1969; Sturman et al., 1970). Hypermethioninaemia may also be found in some forms of tyrosinaemia (Scriver et al., 1966), in severe liver disease (Walshe, 1953; Iber et al., 1957), and in association with a deficiency of hepatic S-adenosylmethionine synthetase activity (Gout $e$ t al., 1977).

In 1970, the screening programme for phenylketonuria at this hospital was extended to include the detection of homocystinuria in the newborn by measuring blood methionine concentrations. The results of this additional study are presented in this report.

\section{Methods}

The sample. Since May 1970 the neonatal screening laboratory at this hospital has screened all babies born in an area corresponding to that now under the 
auspices of the North-east and North-west Thames Regional Health Authorities. When the National Health Service was reorganised in 1974 the area from which patients were drawn changed slightly; small parts of Buckinghamshire and Berkshire were then excluded.

Collection of specimens. On or after the 6th day of life and in most instances up to the 14th day, midwives or health visitors collected blood, obtained by heel prick, on to absorbent cards (supplied by the Department of Health and Social Security; Code no. HMR 101/6) which were then posted to the laboratory in protective plastic covers.

Blood methionine assay. The method was basically that of Guthrie (1968). Dried blood spots of $6.4 \mathrm{~mm}$ in diameter were punched out of the cards and placed on the surface of an agar plate containing the inhibitor methionine sulphoximine and spores of Bacillus subtilis (strain ATCC-6633). Standard controls which consisted of expired donor bloods containing a range of $\mathrm{L}$-methionine concentrations (1-20 $\mathrm{mg} / 100 \mathrm{ml} ; 67-1342 \mu \mathrm{mol} / \mathrm{l})$ were also included on the plate. Plates were incubated overnight at $37^{\circ} \mathrm{C}$. The inhibitor suppresses growth of $B$. subtilis unless methionine is present in sufficient concentrations. The methionine concentration in the blood sample was determined by comparing the diameter of the growth zone near the blood spot with that of standard controls.

Other laboratory investigations. Amino-acids were eluted from blood spots with ethanol $(70 \%$ by vol. in water), separated by thin-layer chromatography and located on separate layers with ninhydrin and iodoplatinate reagents (Ersser and Smith, 1976). Amino-acids in plasma and urine were analysed by both thin-layer and quantitative ion-exchange chromatography (Ersser, 1976).

\section{Results and discussion}

Overall findings. During a $7 \frac{1}{2}$-year period blood methionine concentrations were determined in 670764 neonates. Raised values were initially detected in 147 infants and 55 of these still had raised blood methionine levels when retested 2-6 weeks later (Table 1). Of the babies who had abnormal blood methionine concentrations in the 2nd test, 3 had different forms of homocystinuria, one had a severe form of tyrosinaemia (tyrosinosis), one had hypermethioninaemia associated with abnormal liver function tests, and 48 had transient hypermethioninaemia which resolved uneventfully. The other 2 babies were not fully investigated; one went
Table 1 The prevalence of hypermethioninaemia in 670764 neonates

\begin{tabular}{|c|c|c|c|c|c|}
\hline \multirow[t]{2}{*}{ Year } & \multirow[t]{2}{*}{$\begin{array}{l}\text { No. } \\
\text { screened }\end{array}$} & \multicolumn{2}{|c|}{$\begin{array}{l}\text { No. with raised blood } \\
\text { methionine concentration } \\
(>4 \mathrm{mg} / 100 \mathrm{ml} ; \\
>268 \mu \mathrm{mol} / \mathrm{l})\end{array}$} & \multirow[t]{2}{*}{$\begin{array}{l}\text { Homocy- } \\
\text { stinuria } \\
\text { confirmed } \\
(n=3)\end{array}$} & \multirow{2}{*}{$\begin{array}{l}\text { Transient } \\
\text { hyper- } \\
\text { methionin- } \\
\text { aemia } \\
(n=48)\end{array}$} \\
\hline & & $\begin{array}{l}\text { lst test } \\
(n=147)\end{array}$ & $\begin{array}{l}\text { 2nd test } \\
(n=55)\end{array}$ & & \\
\hline $1970 *$ & 67134 & 24 & 6 & 1 & 4 \\
\hline 1971 & 103540 & 27 & 15 & 1 & 13 \\
\hline 1972 & 96286 & 26 & 17 & 1 & 15 \\
\hline 1973 & 91017 & 22 & 5 & 0 & 5 \\
\hline 1974 & 82523 & 9 & 7 & 0 & 7 \\
\hline 1975 & 77439 & 27 & 4 & 0 & 4 \\
\hline 1976 & 76794 & 6 & 1 & 0 & 0 \\
\hline 1977 & 76031 & 6 & 0 & 0 & 0 \\
\hline
\end{tabular}

abroad and the other, who had transient hypermethioninaemia without homocystinuria, was admitted to another hospital with severe congenital abnormalities of the central nervous system.

Although initial tests were generally done on specimens obtained 6-14 days after birth, some specimens were not entirely satisfactory and repeat samples were needed before an accurate value could be obtained for a suspected abnormal blood methionine concentration. Since 1971, about $5 \%$ of all first specimens have been unsatisfactory.

Transient hypermethioninaemia. 48 of the 517939 babies screened in the period 1970 to 1975 had a transient hypermethioninaemia of at least 3 weeks' duration but this resolved uneventfully in half of them by the 3rd month of life and in all of them by the 5th month. Several of these infants had very high protein intakes and in such cases mothers were advised to change to a milk with a lower protein content. None of the infants with transient hypermethionaemia was known to have been breast fed but our records on this point were unfortunately incomplete. One infant whose blood methionine concentration increased to $1342 \mu \mathrm{mol} / \mathrm{l}$ during a 3-month period was grossly overweight (height, 25 th centile; weight, 90th centile); he had been weaned early and was receiving large amounts of protein (protein intake from milk alone was $5 \mathrm{~g} / \mathrm{kg}$ per day). Appropriate adjustment of his diet was accompanied by a rapid reduction of blood methionine to a normal concentration.

Transient hypermethioninaemia was not detected in the 152825 neonates screened in 1976 and 1977. There was a striking reduction in the incidence of transient hypermethioninaemia in the girls after $1972(\mathrm{P}<0.01)$ and in the boys after $1975(\mathrm{P}<0.01)$ (Figure). There were no obvious changes in methods of sample collection or analysis which could have 


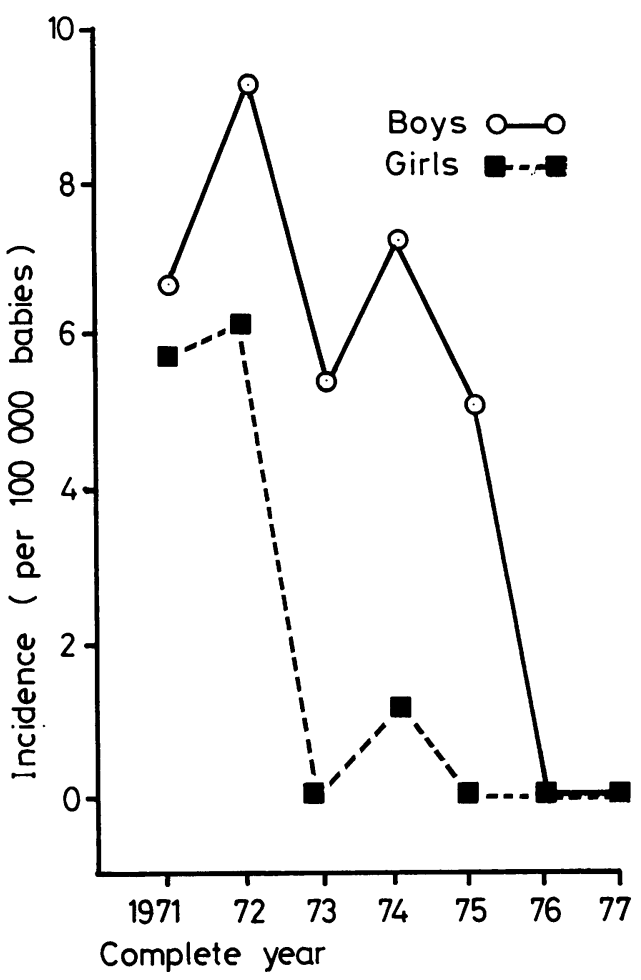

Figure The incidence of transient hypermethioninaemia in baby boys and girls.

accounted for this. The most likely explanation is the change in infant feeding practice which has taken place in the UK. A reduction in the protein content of infant milk formulae, later introduction of solids, and a renewal of interest in breast feeding may all have contributed.

The maximum blood methionine concentrations recorded in boys and girls with transient hypermethioninaemia were similar (boys: mean $12 \mathrm{mg}$ / $100 \mathrm{ml}(805 \mu \mathrm{mol} / \mathrm{l})$, gross range $5-20 \mathrm{mg} / 100 \mathrm{ml}$ (336-1342 $\mu \mathrm{mol} / \mathrm{l})$; girls: mean $11 \mathrm{mg} / 100 \mathrm{ml}$ (738 $\mu \mathrm{mol} / \mathrm{l})$, gross range $7-16 \mathrm{mg} / 100 \mathrm{ml}(459-1072$ $\mu \mathrm{mol} / \mathrm{l})$ ). These maximum values tended to occur later in girls than in boys (girls: mean $\mathbf{4 5}$ days, gross range 21-87; boys: mean 30 days, gross range 6-75) but the difference was not significant. Differences in the periods between sampling in different individuals and the small number of affected infants suggest that this finding should be interpreted with caution.

Homocystinuria. During the first 3 years of the screening programme homocystinuria was confirmed in 3 infants (Table 2) giving an incidence of one in
88987 during that period. One required treatment with a low methionine diet, one responded to treatment with pyridoxine, and the $3 \mathrm{rd}$ had a transient form which responded to a low-protein diet combined with pyridoxine supplement, and resolved within a year so that no further treatment was required. Table 2 compares the initial blood methionine concentrations in these patients. The infant with the pyridoxine-responsive form had lower initial blood methionine concentrations than the infant who responded only to diet. Levy et al. (1971) observed that an infant with the pyridoxine-responsive form had a normal blood methionine concentration at 4 days. Brenton and Cusworth (1971) found that clinical manifestations were less severe in the pyridoxine-responsive form.

No further cases of homocystinuria have been detected here since 1972; the change in incidence between the periods $1970-72$ and $1973-77$ is significant $(\mathrm{P}<0 \cdot 05)$.

Other conditions which were associated with hypermethioninaemia. A baby boy who was asymptomatic at the time of detection had hypermethioninaemia associated with an acute form of tyrosinaemia (tyrosinosis). The blood methionine concentration was only slightly raised at 6 days but had increased further by 3 weeks. Further investigations showed the presence of tyrosinaemia, tyrosyluria, and a proximal renal tubular defect. Failure to thrive, liver dysfunction, and defective blood coagulation soon became evident and despite attempts to control blood methionine and tyrosine concentrations the child died at 14 weeks. Gjessing and Halvorsen (1965) and Larochelle et al. (1967) concluded that the hypermethioninaemia which occurs in acute tyrosinosis is due to severe liver damage, but this was contested by Gaull et al. (1968) who suggested that an unidentified abnormality caused both the hypermethioninaemia and the tyrosinaemia. Linblad et al. (1977) suggested that some severe forms of hereditary tyrosinaemia may be associated with a fumarylacetoacetase deficiency and that the resulting metabolites, succinyl acetate and succinylacetone, are toxic to the liver and kidneys.

Another baby boy, born in 1970 , had a raised blood methionine concentration (about $10 \mathrm{mg} / 100$ $\mathrm{ml} ; 671 \mu \mathrm{mol} / \mathrm{l})$ and raised serum alkaline phosphatase, alanine transferase, and aspartate transferase activities which persisted into the 2nd year of life. No other biochemical abnormality was detected and unlike the otherwise similarly affected infants described by Komrower and Robins (1969) he was not anaemic. The child developed normally and the condition resolved spontaneously without treatment or change of diet. 
Table 2 Summary of findings in three patients with homocystinuria and a patient with a severe form of tyrosinosis

\begin{tabular}{|c|c|c|c|c|c|c|}
\hline \multirow[t]{2}{*}{ Disease } & \multirow[t]{2}{*}{ Sex } & \multirow[t]{2}{*}{$\begin{array}{l}\text { Year of } \\
\text { detection }\end{array}$} & \multicolumn{2}{|c|}{$\begin{array}{l}\text { Blood methionine } \\
\text { concentrations } \mathrm{mg} / 100 \mathrm{ml} \\
(\mu \mathrm{mol} / \mathrm{l})\end{array}$} & \multirow[t]{2}{*}{ Other laboratory findings } & \multirow[t]{2}{*}{ Treatment and outcome } \\
\hline & & & $\begin{array}{l}\text { Age } \\
\text { (6-7 days) }\end{array}$ & $\begin{array}{l}\text { Age } \\
\text { (3-4 weeks) }\end{array}$ & & \\
\hline $\begin{array}{l}\text { Homocystinuria } \\
\text { responding only } \\
\text { to diet }\end{array}$ & $\mathbf{M}$ & 1970 & $20(1342)$ & $20(1342)$ & $\begin{array}{l}3 \text { weeks } \\
\text { Plasma homocystine } 0.25-0.5 \\
\text { mg } / 100 \mathrm{ml} \text {. } \\
\text { Urine analysis: positive cyanide- } \\
\text { nitroprusside test. Increased } \\
\text { excretion of homocystine }\end{array}$ & $\begin{array}{l}8 \text { weeks } \\
\text { No response to pyridoxine. } \\
\text { Biochemical response to low } \\
\text { methionine diet } \\
8 \text { years } \\
\text { Clinically normal. Controlled by low } \\
\text { methionine diet }\end{array}$ \\
\hline $\begin{array}{l}\text { Homocystinuria } \\
\text { pyridoxine } \\
\text { responsive }\end{array}$ & $\mathbf{M}$ & 1971 & $\begin{array}{l}12-15 \\
(805-1007)\end{array}$ & 15 (1007) & $\begin{array}{l}3 \text { months } \\
\text { Plasma methionine }>20 \mathrm{mg} / 100 \\
\text { ml, homocystine } 0.78 \mathrm{mg} / 100 \mathrm{ml} \\
\text { Urine analysis: weakly positive } \\
\text { cyanide-nitroprusside test. } \\
\text { Increased excretion of } \\
\text { homocystine }\end{array}$ & $\begin{array}{l}3 \text { months } \\
\text { Responded to low protein diet. } \\
6 \text { months } \\
\text { Responded to pyridoxine } 250 \mathrm{mg} \\
\text { twice daily. } \\
7 \text { years } \\
\text { Controlled with pyridoxine. No } \\
\text { clinical manifestations of } \\
\text { homocystinuria. History of asthma } \\
\text { and chest infections. Cysts in right } \\
\text { upper lobe-cause unknown. }\end{array}$ \\
\hline $\begin{array}{l}\text { Homocystinuria } \\
\text { transient }\end{array}$ & $\mathbf{F}$ & 1972 & $\begin{array}{l}10-12 \\
(671-805)\end{array}$ & $20(1342)$ & $\begin{array}{l}6 \text { weeks } \\
\text { Urine analysis: intermittently } \\
\text { positive cyanide-nitroprusside } \\
\text { test }\end{array}$ & $\begin{array}{l}8 \text { weeks } \\
\text { Responded to low protein diet and } \\
\text { pyridoxine } \\
1 \text { year } \\
\text { Blood methionine normal on normal } \\
\text { diet and without pyridoxine } \\
\text { supplements } \\
5 \text { years } \\
\text { Clinically and biochemically normal }\end{array}$ \\
\hline $\begin{array}{l}\text { Tyrosinosis } \\
\text { (tyrosinaemia) }\end{array}$ & $\mathbf{M}$ & 1976 & $4(268)$ & $11(738)$ & $\begin{array}{l}3 \text { weeks } \\
\text { Plasma tyrosine } 800 \mu \mathrm{mol} / 1 \\
5-6 \text { weeks } \\
\text { Serum phosphate } 0.88 \mathrm{mmol} / 1 \text {, } \\
\text { calcium } 2 \cdot 15 \mathrm{mmol} / 1 \text {, alkaline } \\
\text { phosphatase } 1079 \mathrm{IU} / 1 \text {. } \\
\text { Urine analysis: aminoaciduria } \\
\text { (generalised), glucosuria, tyro- } \\
\text { syluria. Megaloblastic anaemia. } \\
\text { Abnormal clotting function }\end{array}$ & $\begin{array}{l}\text { Treatment with a diet low in } \\
\text { methionine, phenylalanine, and } \\
\text { tyrosine produced a rapid reduction } \\
\text { in plasma tyrosine but raised } \\
\text { plasma methionine persisted. The } \\
\text { child developed hepatospleno- } \\
\text { megaly with ascites and died at } 3 \\
\text { months after pulmonary haemor- } \\
\text { rhage. Early cirrhosis of the liver } \\
\text { was present }\end{array}$ \\
\hline
\end{tabular}

\section{Discussion and conclusions}

During the early years of the neonatal screening programme at this hospital most bottle-fed infants in the UK were receiving cows' milk preparations with a high protein content (giving neonates about $5 \mathrm{~g}$ protein $/ \mathrm{kg}$ per day) and many of these infants were also receiving solid foods by 4 weeks (Black, 1971; Shukla et al., 1972; Davies, 1973). The association of neonatal hypermethioninaemia with a high protein intake had already been recognised (Komrower and Robins, 1969), and Sturman et al. (1970) suggested that the high methionine:cystine ratio of the protein in cows' milk was inappropriate for human infants. Reports on the possible harmful effects of infantile overnutrition (Taitz, 1971; Menkes et al., 1972; Shukla et al., 1972) may have influenced such feeding practices as the early introduction of solid foods, and may have contributed to the initial reduction in the incidence of neonatal hypermethioninaemia in 1973. Several 'modified' milks with protein concentrations of $1.8 \mathrm{~g}$ per 100 $\mathrm{ml}$ were introduced in 1973 and 1974. Also in the period from about 1970 to 1972 , maternity units began to use infant milk formulae which were accurately diluted and prepacked by the manufacturers.

The apparent disappearance of transient neonatal hypermethioninaemia in 1976 may have been due to the withdrawal of high-protein milks - such as national dried full cream milk-the widespread introduction of infant milk preparations with a protein content and casein:lactalbumin ratio approaching that of human breast milk, and to the publication Present-day Practice in Infant Feeding (Department of Health and Social Security, 1974) which put forward official recommendations for changes in infant feeding practice. The reason why the girls 
but not the boys responded as early as 1973 is uncertain but could be due to a difference in ability to metabolise methionine or to a difference in total milk intake. Whatever the cause these results suggest that the protein intake, or more specifically the methionine intake, of infants decreased in 1973 and decreased further in 1976.

The apparent failure to detect homocystinuria since 1972 coincided with the reduction in the incidence of neonatal hypermethioninaemia. No 'missed' cases of homocystinuria in the areas concerned have yet been brought to our notice but the disease may not be obvious in the early stages. Thus, it appears that the earlier moves away from breast feeding (Newson and Newson, 1962) and the tendency towards infantile overnutrition were conducive to the detection of homocystinuria by neonatal screening programmes which measured blood methionine concentration in early infancy. Ironically, better infant feeding practices necessitate a reassessment of the methods used to detect homocystinuria. Furthermore possible similar effects on the neonatal screening of other inborn errors of amino-acid metabolism should be borne in mind.

These findings, and the studies of Wilcken and Turner (1978) in New South Wales, suggest that the true rate of homocystinuria is greater than that indicated by neonatal screening programmes. Infants with mild forms of the disease are even less likely to be detected. Estimates of the incidence of homocystinuria have varied widely from one area to another. This could be partly attributed to different methods of screening and to different patterns of infant feeding. At present there is no justification for national screening of homocystinuria early in the neonatal period and the reliability of the Guthrie method needs to be carefully reassessed.

The concentration of methionine in blood is normally $<67 \mu \mathrm{mol} / 1$ and the cut-off point of 268 $\mu \mathrm{mol} / \mathrm{l}$ used in the screening programme may now be too high. During a trial period, initially for one year, all infants screened at this centre who have blood methionine concentrations of $2 \mathrm{mg} / 100 \mathrm{ml}(134$ $\mu \mathrm{mol} / \mathrm{l})$ or more will be further investigated. However, recent experience suggests that this procedure will not improve the detection of homocystinuria. Furthermore, Wilcken and Turner (1978) suggest that even including a test for urinary homocystine in a neonatal screening programme at 6 weeks does not ensure detection of the disease.

We gratefully acknowledge the advice and help given by Dr D. Brenton, Dr Sylvia Darke, Miss Dorothy Francis, Mr R. A. Hendey, Dr A. D. Patrick, and Mrs Jean Shepherd.

\section{References}

Black, A. E. (1971). Infant feeding patterns and social class (abstract). Proceedings of the Nutrition Society, 30, 30A-32A.

Brenton, D., and Cusworth, D. C. (1971). The response of patients with cystathionine synthase deficiency to pyridoxine. In Inherited Disorders of Sulphur Metabolism, pp. 264-274. Edited by N. A. J. Carson and D. N. Raine. Churchill-Livingstone: Edinburgh.

Davies, D. P. (1973). Plasma osmolality and feeding practices of healthy infants in the first three months of life. British Medical Journal, 2, 340-342.

Department of Health and Social Security (1974). Present-day Practice in Infant Feeding. Reports on Health and Social Subjects No. 9. HMSO: London.

Ersser, R. S. (1976). A fast automated ion-exchange chromatographic method for analysis of plasma aminoacids. Medical Laboratory Sciences, 33, 257-263.

Ersser, R. S., and Smith, I. (1976). Aminoacids. In Chromatographic and Electrophoretic Techniques, fourth edition, volume 1, pp. 75-108. Edited by I. Smith and J. W. T. Seakins. Heinemann Medical: London.

Gaull, G. E., Rassin, D. K., and Sturman, J. A. (1968). Letter: Significance of hypermethioninaemia in acute tyrosinosis. Lancet, 1, 1318-1319.

Gjessing, L. R., and Halvorsen, S. (1965). Letter: Hypermethioninaemia in acute tyrosinosis. Lancet, 2, 1132-1133.

Gout, J-P., Serre, J-C., Dieterlen, M., Antener, I., Frappat, P., Bost, M., and Beaudoing, A. (1977). Une nouvelle cause d'hypermethioninémie de l'enfant; le deficit en S-adenosylmethionine-synthetase. Archives françaises de pédiatrie, 34, 416-423.

Guthrie, R. (1968). Screening for inborn errors of metabolism in the newborn infant: a multiple test program. Birth Defects Original Article Series, 4, No. 6, 92-98.

Iber, F. L., Rosen, H., Levenson, S. M., and Chalmers, T. C. (1957). Plasma aminoacids in patients with liver failure. Journal of Laboratory and Clinical Medicine, 50, 417-425.

Komrower, G. M., Lambert, A. M., Cusworth, D. C., and Westall, R. G. (1966). Dietary treatment of homocystinuria. Archives of Disease in Childhood, 41, 666-671.

Komrower, G. M., and Robins, A. J. (1969). Plasma amino acid disturbance in infancy. I. Hypermethioninaemia and transient tyrosinaemia. Archives of Disease in Childhood, 44, 418-421.

Larochelle, J., Mortenazi, A., Belanger, M., Tremblay, M., Claveau, J. C., and Aubin, G. (1967). Experience with 37 infants with tyrosinaemia. Canadian Medical Association Journal, 97, 1051-1054.

Levy, H. L., Shih, V. E., Madigan, P. M., Karolkewicz, V., Carr, J. R., Lum, A., Richards, A. A., Crawford, J. D., and MacCready, R. A. (1969). Hypermethioninaemia with other hyperaminoacidaemias. American Journal of Diseases of Children, 117, 96-103.

Levy, H. L., Shih, V. E., and MacCready, R. A. (1971). Screening for homocystinuria in the newborn and mentally retarded population. In Inherited Disorders of Sulphur Metabolism, pp. 235-244. Edited by N. A. J. Carson and D. N. Raine. Churchill-Livingstone: Edinburgh.

Linblad, B., Lindstedt, S., and Steen, G. (1977). On the enzymic defects in hereditary tyrosinaemia. Proceedings of the National Academy of Sciences of the United States of America, 74, 4641-4645.

Menkes, J. H., Welcher, D. W., Levi, H. S., Dallas, J., and Gretsky, N. E. (1972). Relationship of elevated blood tyrosine to the ultimate intellectual performance of premature infants. Pediatrics, 49, 218-224. 
Mudd, S. H., Uhlendorf, B. W., and Hinds, K. R. (1970). Deranged $B_{12}$ metabolism. Studies of fibroblasts grown in tissue culture. Biochemical Medicine, 4, 215-239.

Mudd, S. H., Uhlendorf, B. W., Freeman, J. M., Finkelstein, J. D., and Shih, V. E. (1972). Hypercystinuria associated with decreased methioninetetrahydrofolate reductase activity. Biochemical and Biophysical Research Communications, 46, 905-912.

Newson, L. J., and Newson, E. (1962). Breast feeding in decline. British Medical Journal, 2, 1744-1745.

Scriver, C. R., Clow, C. L., and Silverberg, M. (1966). Letter: Hypermethioninaemia in acute tyrosinosis. Lancet, 1, 153-154.

Shukla, A., Forsyth, H. A., Anderson, C. M., and Marwah, S. M. (1972). Infantile over-nutrition in the first year of life: a field study in Dudley, Worcestershire. British Medical Journal, 4, 507-515.

Sturman, J. A., Gaull, G., and Räihä, N. C. R. (1970). Absence of cystathionase in human fetal liver. Is cystine essential? Science, 169, 74-76.

Taitz, L. S. (1971). Infantile over-nutrition among artificiallyfed infants in the Sheffield region. British Medical Journal, $1,315-316$.

Thalhammer, O. (1975). Frequency of inborn errors of metabolism especially PKU in some representative newborn screening centres around the world. A collaborative study. Humangenetik, 30, 273-286.

Walshe, J. M. (1953). Disturbances of aminoacid metabolism following liver injury. Quarterly Journal of Medicine, 22, 483-505.

Wilcken, B., and Turner, G. (1978). Homocystinuria in New South Wales. Archives of Disease in Childhood, 53, 242-245.

Correspondence to Dr P. D. Whiteman, Wellcome Research Laboratories, Langley Court, Beckenham, Kent.

Received 24 October 1978

Dr I. B. Sardharwalla of the Willink Biochemical Genetics Unit, Royal Manchester Children's Hospital, was invited to comment:

Our own experience is similar to that described by Whiteman et al. Most infants in the North-western Region are tested between 10 and 14 days after birth (primarily for phenylketonuria) and to date over half a million babies have been screened. The method used is one-dimensional paper chromatography of plasma (Scriver et al., 1964) which can detect 6 related amino-acid abnormalities, including hypermethioninaemia (Sardharwalla et al., 1972). This technique is sufficiently sensitive to detect a plasma methionine concentration of $0.2 \mathrm{mmol} / 1(2.98 \mathrm{mg} /$ $100 \mathrm{ml}$ ). If plasma methionine concentration is $>0.6 \mathrm{mmol} / 1(>8.9 \mathrm{mg} / 100 \mathrm{ml})$ immediate steps are taken to have the baby brought to the metabolic unit for detailed investigations. If, however, on initial screening the plasma methionine is between
0.2 and $0.6 \mathrm{mmol} / 1$ the test is repeated after one month. If the repeat test shows a normal pattern no further action is taken, but a persistent abnormality is investigated.

Of 12 babies identified because initial levels of plasma methionine were $>0.6 \mathrm{mmol} / 1$, homocystinuria was confirmed in 5 of them, one had galactosaemia with liver damage, one had $\alpha$-1-antitrypsin deficiency with liver involvement, and one was found to have bacterial hepatitis after septicaemia. In the other 4 babies in whom raised methionine was associated with raised plasma tyrosine we were able to establish the diagnosis of hereditary tyrosinaemia.

I share the view that some infants with homocystinuria will not be identified by any neonatal screening method designed to detect raised plasma methionine. One baby with homocystinuria, a younger sibling of a known case, did not have a raised level of plasma methionine when tested on the 10th and 17th days after birth, but the level of homocystine in the blood was increased when measured on day 17.

We too have noticed a steady fall in the incidence of transient hypermethioninaemia since 1973 and have seen this trend reflected in the incidence of the other aminoacidaemias. This is shown in the Table. I agree that this decline is probably related to the wider use of low-protein milk formulae but would suggest that the occurrence of some transient aminoacidaemias may be due to temporary immaturity of enzymes necessary in the metabolism of relevant amino-acids.

Table Incidence of transient aminoacidaemias per 100000 infants screened (1972-78)

\begin{tabular}{|c|c|c|c|c|c|c|c|}
\hline Amino-acids & 1972 & 1973 & 1974 & 1975 & 1976 & 1977 & 1978 \\
\hline $\begin{array}{l}\text { Methionine } \\
\text { Phenylalanine (not } \\
\text { exceeding } 0.3\end{array}$ & 218 & 222 & 136 & 155 & 99 & 87 & 58 \\
\hline $\begin{array}{l}\text { mmol/1) } \\
\text { Tyrosine } \\
\text { Generalised increase }\end{array}$ & $\begin{array}{l}232 \\
777\end{array}$ & ${ }^{76}$ & ${ }^{90}$ & $\begin{array}{l}122 \\
580\end{array}$ & $\begin{array}{r}78 \\
302\end{array}$ & $\begin{array}{l}40 \\
77\end{array}$ & $\begin{array}{l}48 \\
88\end{array}$ \\
\hline $\begin{array}{l}\text { of amino-acids } \\
\text { Miscellaneous (basic } \\
\text { amino-acids, glyci } \\
\text { etc.) }\end{array}$ & $e^{414}$ & 281 & 247 & 214 & 175 & 129 & 144 \\
\hline
\end{tabular}

*Complete data not available.

\section{References}

Sardharwalla, I. B., Komrower, G. M., Bridge, C., and Gordon, D. B. (1972). One-dimensional chromotography of plasma in Manchester. Annals of Clinical Biochemistry, 9, 126-128.

Scriver, C. R., Davies, E., and Cullen, A. M. (1964). Application of a simple micromethod to the screening of plasma for a variety of aminoacidopathies. Lancet, 2, 230-232. 